\title{
A scientific note on Varroa destructor resistance to coumaphos in the United States
}

\author{
Jeff S. PETTIS \\ USDA-ARS Bee Research Laboratory, Bldg 476 BARC-E, Beltsville, MD 20705, USA
}

(Received 10 January 2003; revised 27 May 2003; accepted 13 June 2003)

Varroa destructor / resistance / acaricide / coumaphos / USA

The beekeeping industry has limited products to control the parasitic mite Varroa destructor Anderson \& Trueman. Mite resistance to acaricides is becoming all too common in many areas of the world. V. destructor resistance to fluvalinate in Italy (Lodesani et al., 1995) was followed by detection of fluvalinate resistant $V$. destructor in the United States (Baxter et al., 1998; Elzen et al., 1998; Pettis et al., 1998). In response to the loss in effectiveness of fluvalinate, the United States Environmental Protection Agency (EPA) granted CheckMite+, a slow release strip formulation of coumaphos, a limited use permit in 1998. Coumaphos in a different formulation has been used in Europe but the US was the first market to use the slow release strips. In 2003 the US will be in its fifth year of the use of CheckMite+ ${ }^{\mathrm{TM}}$ (Bayer) for $V$. destructor control.

In the fall of 2001, a commercial beekeeper in Maine (migratory between Maine and Florida) complained of high $V$. destructor populations following treatment of his colonies with CheckMite+. To determine if acaricide resistance was involved, experiments were conducted on mite populations in Maine and compared with mite populations in Maryland using a field assay originally developed to detect fluvalinate resistance (Pettis et al., 1998) that was modified to detect coumaphos resistance. Additionally, resistance assays were conducted on colonies in two commercial beekeeping operations in an area of Florida where the Maine beekeeper overwinters his colonies.

The assay consisted of a $10 \times 20 \mathrm{~mm}$ section of $10 \%$ CheckMite+ strip stapled to an index card and placed in a quart (ca. $450 \mathrm{~mL}$ ) glass jar with a modified screen lid (Pettis et al., 1998). The assay was conducted by collecting samples of ca. 150 bees from each hive, placing them in the jars and $6 \mathrm{~h}$ later determining the number of mites killed. This assay was similar to the assay developed to test for fluvalinate resistance but the results were recorded in six hours instead of 24 hours as coumaphos acted faster to kill mites than did the fluvalinate. After recording the number of mites killed, heat or an alcohol/soap wash was used to remove any mites remaining on bees. Percent mortality was calculated as number of mites killed in $6 \mathrm{~h} /$ total mites in the jar) $\times 100$. The assay was conducted using a single lot number (\#615168) of CheckMite+ strips on 24 colonies in Maine, 44 colonies in Beltsville, Maryland, and 24 colonies in Florida, 12 in each of two locations. The Maryland mite populations were assayed to allow for a comparison with a presumed "susceptible" population of mites. V. destructor in one of the USDA-ARS apiaries (Maryland \#1, n = 20) had only been exposed to CheckMite+ for one season and were presumed susceptible, the second apiary (Maryland \#2, $\mathrm{n}=24$ ) contained bees and mites that had originally come from Florida in 2000 and the history of acaricide use for this apiary was unknown. Percent mortality of mites was compared between locations using a general liner model and differences between means were analyzed using an LSD test (SAS, 1988).

There was only $13 \%$ mortality for the mites in Maine, while mites in Maryland exhibited 80$100 \%$ mortality and the mite mortality in two Florida apiaries were $7 \%$ and $80 \%$ (Tab. I). Significantly lower mite mortality was observed in Maine and Florida \#2 compared to the other sites. Additionally, assay results from the apiaries in Maine were from colonies in which two legally

* Corresponding author: pettisj@ba.ars.usda.gov 
Table I. V. destructor mite percent mortality following six hours of exposure to coumaphos in an assay that consists of collecting ca. 150 live worker honey bees with mites per colony. Letters indicate significant differences between treatments (ANOVA, $\mathrm{F}=71.94,3 \mathrm{df}, P<0.0001$ ).

\begin{tabular}{lccccc}
\hline Location & Colonies sampled & \multicolumn{2}{c}{ Percent mortality } & \multicolumn{2}{c}{ Mites per sample } \\
\cline { 3 - 6 } & & mean \pm SE & range & mean \pm SE & range \\
\hline Maine & 24 & $13 \pm 3.0 \mathrm{a}$ & $0-45$ & $44 \pm 3$ & $32-67$ \\
Maryland \#1 & 24 & $89 \pm 2.1 \mathrm{~b}$ & $67-100$ & $21 \pm 4$ & $12-37$ \\
Maryland \#2 & 20 & $98 \pm 1.0 \mathrm{~b}$ & $80-100$ & $24 \pm 3$ & $14-41$ \\
Florida \#1 & 12 & $80 \pm 3.7 \mathrm{~b}$ & $50-100$ & $15 \pm 4$ & $8-22$ \\
Florida \#2 & 12 & $6.8 \pm 1.9 \mathrm{a}$ & $0-16$ & $26 \pm 5$ & $28-37$ \\
\hline
\end{tabular}

applied CheckMite+ strips had failed to control the mites over a 25-day fall treatment period. The average number of mites per bee (ca. $0.5 \mathrm{mites} / \mathrm{bee}$ ) from the assay in Maine gives an indication of the lack of control provided during the treatment of these colonies in the fall of 2001 .

The appearance of mites resistant to coumaphos, the active ingredient in CheckMite+, in only three years of use is disturbing in light of the limited control alternatives. The current study documents high levels of mite resistance in Florida and Maine; these findings are supported by Elzen and Westervelt (2002) who found evidence of limited resistance levels in Florida. The US currently has $V$. destructor populations that are resistant to fluvalinate and coumaphos and few mite control alternatives are on the horizon. Identification of resistant mites and rotation of chemicals is needed to limit their spread and prolong the use of all acaricides. Based on our findings, it is advised that beekeepers use some means of assessing their mite populations before and especially following treatment with CheckMite+. This same advice is needed when using fluvalinate. We hope that coumaphos-resistant mites are not widespread and that we can prolong the use of all control products using rotation schemes and relying more on resistant stocks of bees and alternative control strategies.
Note scientifique sur la résistance de Varroa destructor au coumaphos aux États-Unis.

Eine wissenschaftliche Notiz über die Resistenz von Varroa destructor gegen Coumaphos in den Vereinigten Staaten.

\section{REFERENCES}

Baxter J., Eischen F., Pettis J., Wilson W.T., Shimanuki H. (1998) Detection of fluvalinateresistant varroa mites in US honey bees, Am. Bee J. 138, 291.

Elzen P.J., Eischen F.A., Baxter J.B., Pettis J., Elzen G.W., Wilson W.T. (1998) Fluvalinate resistance in Varroa jacobsoni from several geographic locations, Am. Bee J. 138, 674-676.

Elzen P.J., Westervelt D. (2002) Detection of Coumaphos resistance in Varroa destructor in Florida, Am. Bee J. 142, 291-292.

Lodesani M., Colombo M., Spreafico M. (1995) Ineffectiveness of Apistan ${ }^{\circledR}$ treatment against the mite Varroa jacobsoni Oud in several districts of Lombardy (Italy), Apidologie 26, 67-72.

Pettis J.S., Shimanuki H., Feldlaufer M.F. (1998) An assay to detect fluvalinate resistance in Varroa mites, Am. Bee J. 138, 538-541.

SAS (1988) SAS/STAT User's Guide version 6.03, Gary, NC. 